\title{
Apoptosis in Bone Defect of Diabetic Rats Treated with Low Intensity Laser: Radiological and Immunohistochemical Approach
}

\author{
Apoptosis en Ratones Diabéticos con Defecto Oseo Tratados con Láser de Baja Intensidad: \\ Evaluación Radiológica e Inmunohistoquímica
}

\begin{abstract}
Jairo Pinheiro da Silva ${ }^{1}$; Camila Albuquerque Mello de Carvalho ${ }^{2}$; Andressa Rodrigues Romualdo ${ }^{1}$; Vagner Sarraipo Schiavoni ${ }^{1}$; Marcello Henrique Nogueira Barbosa ${ }^{3}$ : Marcella Suélen Torrecilla de Moraes ${ }^{1}$; Daniela Petri Cunha Tirapelli'; Valéria de Paula Sassoli Fazan ${ }^{1}$; José Antônio Thomazini ${ }^{1}$ \&Luis Fernando Tirapelli ${ }^{1}$
\end{abstract}

DA SILVA, J. P.; DE CARVALHO, C. A. M.; ROMUALDO, A. R.; SCHIAVONI, V. S.; BARBOSA, M. H. N.; DE MORAES, M. S. T.; TIRAPELLI, D. P. C.; FAZAN, V. P. S.; THOMAZINI, J. A. \& TIRAPELLI, L. F. Apoptosis in bone defect of diabetic rats treated with low intensity laser: Radiological and immunohistochemical approach. Int. J. Morphol., 35(1):178-183, 2017.

SUMMARY: The aim of this study is evaluate the efficacy of $904 \mathrm{~nm}$ laser diode in bone regeneration in the bone defect in diabetic rats. Six groups of 10 male Wistar rats and $2 \mathrm{~mm}$ bone defects drilled on the left and right tibia were used. The diabetic animals were treated with streptozotocin $(40 \mathrm{mg} / \mathrm{kg}$, i.v.). We compared the diode laser doses of treatment of bone defects $50 \mathrm{w}-4 \mathrm{~J} / \mathrm{cm}$ and $100 \mathrm{w}-4 \mathrm{~J} /$. The right tibia was used for immunohistochemical analysis with the apoptosis markers XIAP and Caspase-3 and the left tibia was submitted to computer tomography (CT). Caspase-3 marker showed greater amount of apoptosis in all the untreated groups compared to both laser treatments. There was no statistical significance for XIAP marker. CT scan showed improvement of bone defect area and volume in both laser treated groups, control and diabetic. Therefore the low intensity laser therapy was effective in accelerating bone repair in both, control and diabetic groups. It was evidenced in our study that diabetes influences bone repair negatively.

KEY WORDS: Bone defect; Diabetes mellitus; Laser therapy; Regeneration; Apoptosis.

\section{INTRODUCTION}

Apoptosis is an active physiological process genetically controlled that induces cell death, but its role in the tissue repair still needs investigation (Einhorn, 1998; Dempster et al., 2005).

The bone tissue is a complex system, dynamic and constantly working between formation and bone reabsorption, changing this dynamics particularly after trauma (Dunlop \& Fratzl, 2010) leading to tissue repair. Some metabolic diseases can impair this process of tissue repair, diabetes mellitus (DM) being one of the most common causes of bone repair failure. One of the mechanisms described for this failure is the decreased tissue vascularization due to the increased basement membrane thickness of the vessel wall that would directly affect the tissue metabolism (Fernandes et al., 2005). Although apoptosis might play a role in tissue repair, still very little is known about the apoptosis mechanism in the bone repair process (Imao \& Nagata, 2013).
Low Light Laser Therapy (LLLT) has been applied in different tissues to further enhance and accelerate the process of regeneration and tissue repair, with positive results (Rocha Júnior et al., 2006). The effect of the LLLT in bone tissue is still poorly investigated. Moreover, the association of bone cell apoptosis with the use of low-intensity laser therapy in the regeneration of a bone defect was not yet investigated. This work aimed to study cell apoptosis in bone defects in diabetic rats, subjected or not to LLLT, comparing two different laser doses. The volume of the bone defect was also evaluated using computer tomography (CT).

\section{MATERIAL AND METHOD}

Sixty male adult Wistar rats, aged 3 months, weighing between $280-310 \mathrm{~g}$, from the Animal Care Facility of the

\footnotetext{
${ }^{1}$ Department of Surgery and Anatomy, Surgical Clinic Program, FMRP-USP, Ribeirao Preto-SP, Brazil.

${ }^{2}$ Institute of Biological and Health Sciences, Federal University of Alagoas, Alagoas, Brazil.

${ }^{3}$ Department of Ortopedic and Traumatology, FMRP-USP, Ribeirao Preto-SP, Brazil.

${ }^{4}$ Department of Biomechanics, Medicine and Rehabilitation of the Locomotor Apparatus, FMRP-USP, Ribeirao Preto-SP, Brazil.
} 
University of São Paulo, Campus of Ribeirão Preto were used. The animals were housed in three to five per cage, in a carefully regulated environment maintained at $21^{\circ} \mathrm{C}-23$ ${ }^{\circ} \mathrm{C}, 40 \%-70 \%$ relative air humidity, and $12 / 12 \mathrm{hr}$ light/ dark cycle, receiving tap water and normal rat chow ad libitum throughout the experiment. All procedures adhered to "The ARRIVE guidelines: Animal Research: Reporting In Vivo Experiments, originally published in PLoS Biology, June 2010" and were approved by the Institutional Ethics Committee for Animal Research (CETEA - Comitê de Ética em Experimentacão Animal, protocol number 160/2011). A conscious effort was done to minimize the number of animals used.

Six experimental groups were used ( $\mathrm{N}=10$ per group): Control Group (GC): non-diabetic animals with bone defect not submitted to laser treatment; Control Group 50 (GC50): non-diabetic animals with bone defect and treated with laser $(\lambda=904 \mathrm{~nm})$, with fluency of $50 \mathrm{~J} / \mathrm{cm}^{2}$, for 17 seconds, providing energy $1,7 \mathrm{~J}$; Control Group 100 (GC100): nondiabetic animals with bone defect and treated with laser $(\lambda$ $=904 \mathrm{~nm}$ ), with fluency $100 \mathrm{~J} / \mathrm{cm}^{2}$ for 34 seconds providing energy 3,4 J; Diabetic group (GDI): diabetic animals with bone defect not submitted to laser treatment; Diabetic Group 50 (GD50): diabetic animals with bone defect and treated with laser $(\lambda=904 \mathrm{~nm})$, with fluency of $50 \mathrm{~J} / \mathrm{cm}^{2}$, for 17 seconds, providing energy 1,7 J; and Diabetic Group 100 (GD100): diabetic animals with bone defect and treated with laser $\left(\lambda=904 \mathrm{~nm}\right.$ ), with fluency $100 \mathrm{~J} / \mathrm{cm}^{2}$ for 34 seconds providing energy $3,4 \mathrm{~J}$.

STZ $(60 \mathrm{mg} / \mathrm{Kg})$ or citrate buffer injections were performed as described previously (Fazan et al., 2009; Oliveira et al., 2013). The animals were considered diabetic
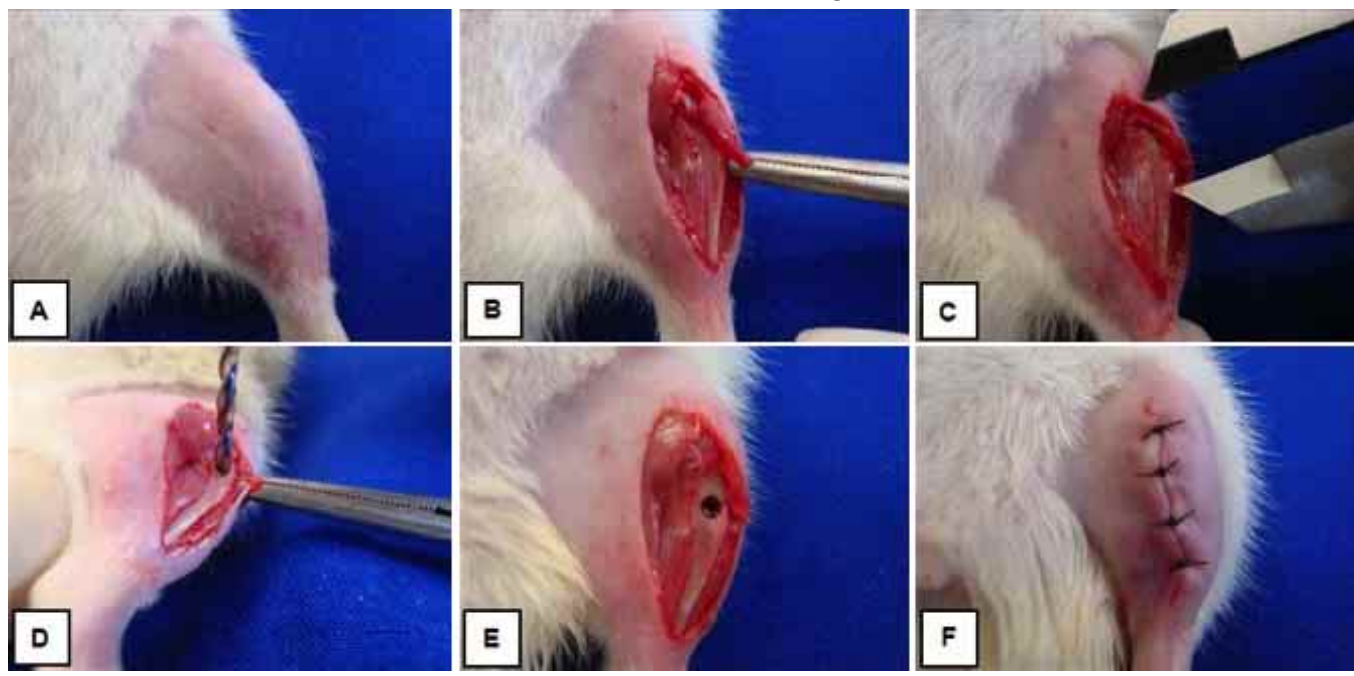

Fig. 1. Surgical steps for the bone defect procedures: (A) digital trichotomy; (B)skin incisión in the tibial region; (C) measurement of the site for the bone defect with a caliper; (D) drilling the bone defect with 2 mm diameter drill; (E)bone defect after drilling; (F) skin suture. 
DA SILVA, J. P.; DE CARVALHO, C. A. M.; ROMUALDO, A. R.; SCHIAVONI, V. S.; BARBOSA, M. H. N.; DE MORAES, M. S. T.; TIRAPELLI, D. P. C.; FAZAN, V. P. S.; THOMAZINI, J. A. \& TIRAPELLI, L. F. Apoptosis in bone defect of diabetic rats treated with low intensity laser: Radiological and immunohistochemical approach. Int. J. Morphol., 35(1):178-183, 2017.

The laser was applied at a single point on the bone defect, immediately after the surgical procedure and in the second, fourth, sixth, eighth, tenth and twelfth day after the surgery. A total of seven applications in 14 days were performed. On the 14th day after surgery, the animals were killed by anesthetic overdose and the tibias were dissected and removed. The right tibia was used for conventional immunohistochemical analysis and the left tibia was frozen and submitted to the CT scan.

For protein expression analysis six animals per group were used. The immunohistochemical reactions were performed with the avidin-biotinperoxidase (Novostain Super ABC Kit - Universal, NCL-ABCu, Novocastra Laboratories Ltd, Newcastle upon Tyne, UK) - (universal Kit mach 4 BIOCARE) method.

The animal tissue was immersed in paraffin. For immunohistochemical analysis, slides were obtained from 5 animals each being sequenced with a thickness of $5 \mu \mathrm{m}$. In each section used for the immunohistochemical reaction, two microscopic fields were selected in the compact bone of the tibia at 400x magnification, where higher concentration of positive or labeled cells (areas of "hot spots") for proteins related to the mechanism of apoptosis (CASPASE 3 - pro-apoptotic and XIAP anti-apoptotic) were present. From the count of the total number of positive (nuclear staining) and negative cells in each microscopic field, the percentage of positive cells was calculated.

For radiological control and evaluation of the bone repair process, CT scans of the left tibia were performed on a CT scanner (Brilliance CT 40-slice models, and 64-slice Big Bore, PHILIPS). The images obtained on CT scans were analyzed using the software Image $\mathbf{J}^{\circledR}$ where a plug-in allowed the estimation of the volume and area of the bone defect.

A Shapiro-Wilk test was performed to test normality for all variables. When normal distribution was present, comparisons were made using analysis of variance (ANOVA) followed by Tukey post-test. On nonparametric variables, the Kruskal-Wallis test was used, followed by Dunns post-test. Analyses were performed in STATISTICA software, version 7.0 and Prism 6.0 GraphicPad. Significance level of $5 \%(\mathrm{p} \leq 0.05)$ was used.

\section{RESULTS}

Nuclear positive staining was observed for CASPASE-3 protein in the diffuse layer of compact bone with several focal sites of greatest expression (Fig. 2), particularly in animal groups GC and GC50; but no significant difference was found between these two groups (Fig. 3). The expression of this protein in groups GC50, GC100, GD50 and GD100 was significantly reduced ( $p<0.0001$, KruskalWallis test) compared to GC. The expression of CASPASE 3 was larger in the GDI group compared to the GC group, with no significant difference between them. Low XIAP protein expression was observed in the compact bone layer of the tibia between the studied groups $\mathrm{p}=0$, Kruskal-Wallis test. There was no significant difference between groups (Fig. 3).

In computed tomography, the volume of the bone defect and the histogram of the coefficient of the tissue in the bone defect was observed, as an indication of how much regeneration was present (Fig. 4). There was a significant difference between the non-diabetic groups treated and untreated. A decrease in the bone defect volume in treated and untreated diabetic group was also observed.

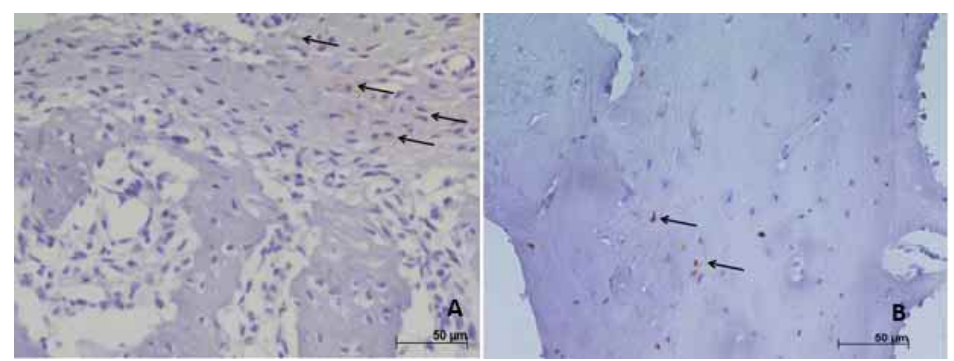

Fig. 2. A) photomicrograph of the tibia compact bone of a GC50 group animal with low positive nuclear staining for CASPASE 3 as Shown By the arrow in the innermost part of this layer. Magnification: 400x. B) photomicrograph of the tibia compact bone of a GC group animal with positive nuclear staining for XIAP (arrows) Magnification:400x.

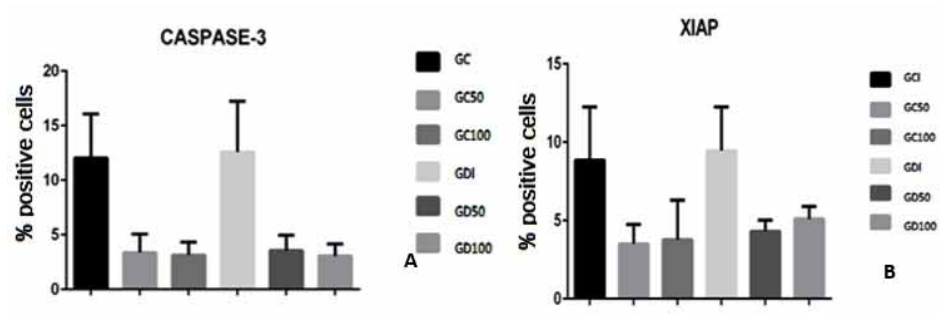

Fig. 3. A) Average ( \pm Standard deviation)protein expression of caspase-3 in the compact bone layer of the tibia between groups studied $(\mathrm{p}<0.0001$, Kruskal- wallis test) B) Average ( $\pm \mathrm{SD}$ ) of the protein expression of XIAP in the layer of compact bone of the tibia between the groups $(\mathrm{p}=0.510$, Kruskalwallis test). 
DA SILVA, J. P.; DE CARVALHO, C. A. M.; ROMUALDO, A. R.; SCHIAVONI, V. S.; BARBOSA, M. H. N.; DE MORAES, M. S. T.; TIRAPELLI, D. P. C.; FAZAN, V. P. S.; THOMAZINI, J. A. \& TIRAPELLI, L. F. Apoptosis in bone defect of diabetic rats treated with low intensity laser: Radiological and immunohistochemical approach. Int. J. Morphol., 35(1):178-183, 2017.
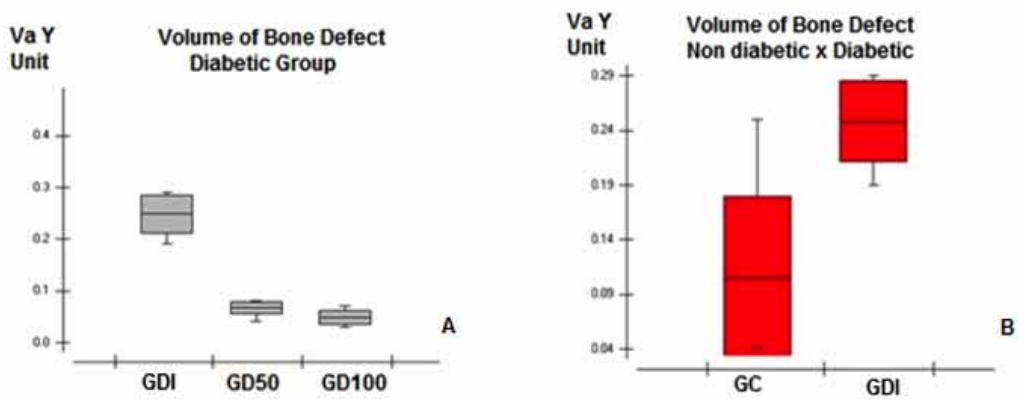

Fig. 4 A) Volume of bone defect in diabetic groups. B) volumen of bone defect, comparing the non- diabetic and diabetic groups.

\section{DISCUSSION}

In our study, we found that the induction with the alloxan was effective in the development of experimental diabetes due to irreversible damage in beta cell, as found by Nascimento et al. (2015), who used this drug and obtained similar results, being it an excellent experimental model.

The expression of Caspase- 3 in the bone defect of the tibia in diabetic rats was lower in the groups undergoing LLLT with the diode laser $(1=904 \mathrm{~nm})$. There was no difference between the groups treated with $50 \mathrm{~W} / \mathrm{cm}^{2}$ and $100 \mathrm{~W} / \mathrm{cm}^{2}$. The expression of XIAP in bone defects of the tibia in diabetic rats was not different in the groups undergoing LLLT with the diode laser. In computed tomography, the volume of the bone defect in the diabetic animals was higher, independently of the treatment.

The osteoclasts are multinucleated giant cells mainly responsible for bone reabsorption that quickly die due to apoptosis in the absence of trophic factors such as macrophage colony stimulating factor (M-CSF) or ligand to receptor nuclear factor kappa B (RANKL - nuclear factor kappa-B ligand). Bcl-2-interacting mediator of cell death (Bim) is a member of BH3, of the BCL-2 family, the only family of pro-apoptotic protein which regulates the mitochondrial apoptosis pathway. It is located in the mitochondria and the interaction between this protein and other BCL-2 family possibly become from oligomerization of $\mathrm{BAX}$ and $\mathrm{BAK}$, leading to cytochrome-c release. Cytochrome-c interacts with APAF-1 and CASPASE-9 to form the apoptosome leading to apoptosis (Tanimoto et al., 2005).

Labeling of caspase- 3 showed a significant difference between the normal control groups compared to those treated with low intensity laser therapy. Also, the diabetic control group increased apoptotic activation when compared to the other treated diabetic groups. Regarding the marking of XIAP, there was no statistical difference between groups (Leo et al., 2012).

The use of computed tomography helped on the evaluation of the size and behavior of the bone defect under the different experimental conditions. Garib et al. (2006) used the CT study to evaluate and monitor the behavior of implants in tibias of rabbits and found that the technique was effective for analysis. In human dentistry, cone beam tomographic evaluations are widely used to evaluate mineralized bone tissue and monitor bone remodeling since this technique allows playback of three-dimensional images of tissues with minimal distortion (Wassal Silveira, 2009). In this work, the diabetic control group presented a larger volume of bone defect compared to the untreated control group. Thus, diabetes interfered negatively in the bone defect repair. The bone defect area results confirmed the bone volume observations.

The area compared to the treated groups, both normal and diabetic patients, and the diabetic group showed a greater area of bone defect than the normal group in our study.

LLLT is currently one of the photobiostimulation modalities most commonly used in rehabilitation. Several studies have demonstrated the positive effect of laser treatment on the bone metabolism, such as osteoblast proliferation (Einhorn), the presence of newly formed blood vessels and increase in alkaline phosphatase activity (Renno et al., 2007). 
DA SILVA, J. P.; DE CARVALHO, C. A. M.; ROMUALDO, A. R.; SCHIAVONI, V. S.; BARBOSA, M. H. N.; DE MORAES, M. S. T.; TIRAPELLI, D. P. C.; FAZAN, V. P. S.; THOMAZINI, J. A. \& TIRAPELLI, L. F. Apoptosis in bone defect of diabetic rats treated with low intensity laser: Radiological and immunohistochemical approach. Int. J. Morphol., 35(1):178-183, 2017.

Nascimento et al. investigated bone healing in diabetic rats using the LLLT. We used 72 rats divided into 4 groups: CTR (non-diabetic control), DBT (diabetic) CTRL (irradiated non-diabetic) and DBTL (irradiated diabetic). The animals underwent surgery with a fac- $19 \mathrm{~mm}$ in femurs. Diabetic animals were also induced with alloxan. The low level laser therapy was performed every 48 hours for seven days. The animals were sacrificed at seven, 18 and 30 days. Serum levels of alkaline phosphatase and bone repair were analyzed. It was found that LLLT significantly increased alkaline phosphatase seven and 18 days $(p<0.001)$ and enhanced bone healing in seven ( $p<0.01), 18(p<0.05)$ and $30(\mathrm{p}<0,01)$ days in diabetic animals. Furthermore, bone healing in diabetic irradiated group was statistically similar to the control group at 30 days ( $p>0.05$ ). Thus, the LLLT increased serum levels of alkaline phosphatase and improved bone healing in diabetic rats alloxan-induced. Thus, LBI helps improve bone formation by direct stimulation of the metabolism of osteoblasts by increasing the synthesis of proteins (collagen) and cellular levels of adenosine triphosphate.

The amount of new bone tissue presented in both irradiated groups was higher than the control group 14 days after surgery. However, when the two treatments were compared, there were no significant differences, suggesting that LLLT was effective to stimulate bone repair both in doses of $50 \mathrm{~J} / \mathrm{cm}^{2}$ and $100 \mathrm{~J} / \mathrm{cm}^{2}$. These data corroborate the study of Miserendino \& Pick (1995), who also showed that the quality of bone repair and the amount of newly formed bone in the group treated with laser $\left(735 \mathrm{~nm}, 16 \mathrm{~J} / \mathrm{cm}^{3}\right.$, with irradiation time of one minute) were higher than the control group.

Therefore, the laser was effective in the reduction of apoptotic proteins, influencing bone regeneration and confirming the CT scan. In fact, the groups irradiated with laser therapy had a lower bone defect area.

In our study, the immunohistochemical and radiological analysis showed difference of the bone defect volume between animals of the non-diabetic and diabetic groups, as well as between the non-irradiated and irradiated groups. Also, it was found that there was a decrease in bone defects and hence in the proteins that participate in the apoptosis process, which therefore assists in regenerating bone defect when the animals were subjected to LLLT.

\section{CONCLUSION}

It is important to report, based that this is the first research checking apoptosis in bone tissue, because of this we had a little difficulty in finding work for discussion.

Therefore, we see what the LLLT with diode laser $(\lambda$ $=904 \mathrm{~nm}$ ) has acted in decreased expression of caspase -3 no defect bone diabetics rat tibia, we also found no difference between the groups treated with $50 \mathrm{~W} / \mathrm{cm}$ and $100 \mathrm{~W} / \mathrm{cm}$.

No significant change in XIAP expression in bone of diabetic rat tibial defects in groups submitted LLLT with the laser diode.

The volume to bone defect in diabetic animals also has compared the greater control and between the same that were treated with LLLT, the dose independent non treatment.

New studies would be required to paragraph increased apoptosis mechanism understanding bone tissue when subjected to LLLT.

DA SILVA, J. P.; DE CARVALHO, C. A. M.; ROMUALDO, A. R.; SCHIAVONI, V. S.; BARBOSA, M. H. N.; DE MORAES, M. S. T.; TIRAPELLI, D. P. C.; FAZAN, V. P. S.; THOMAZINI, J. A. \& TIRAPELLI, L. F. Apoptosis en ratones diabéticos con defecto óseo tratados con láser de baja intensidad: Evaluación radiológica e inmunohistoquímica. Int. J. Morphol., 35(1):178-183, 2017.

RESUMEN: Los objetivos de este estudio fueron evaluar la eficacia del láser diodo de $904 \mathrm{~nm}$ en la regeneración ósea del defecto óseo en ratas diabéticas. Se utilizaron seis grupos de 10 ratas Wistar macho y se generó un defecto óseo de 2 mm en las tibias izquierda y derecha de los animales. El animal diabético fue generado con estreptozotocina (40 mg / kg, i.v.). Se compararon las dosis de tratamiento de los defectos óseos con láser de diodo de $50 \mathrm{w}-4 \mathrm{~J} / \mathrm{cm}$ y $100 \mathrm{w}-4 \mathrm{~J} /$. La tibia derecha fue utilizada para el análisis inmunohistoquímico con los marcadores de apoptosis XIAP y Caspasa-3 y la tibia izquierda fue sometida a tomografía computarizada. El marcador caspasa-3 mostró mayor cantidad de apoptosis en todos los grupos no tratados en comparación con ambos tratamientos con láser. No hubo significación estadística para el marcador XIAP. La tomografía computarizada mostró una mejoría del área y el volumen de los defectos óseos en ambos grupos tratados con láser, control y diabéticos. Por lo tanto, la terapia con láser de baja intensidad fue eficaz en la aceleración de la reparación ósea tanto en los grupos control como en los diabéticos. Se evidenció en nuestro estudio que la diabetes afecta negativamente la reparación ósea.

PALABRAS CLAVE: Defecto óseo; Diabetes mellitus; Terapia láser; Regeneración; Apoptosis. 
DA SILVA, J. P.; DE CARVALHO, C. A. M.; ROMUALDO, A. R.; SCHIAVONI, V. S.; BARBOSA, M. H. N.; DE MORAES, M. S. T.; TIRAPELLI, D. P. C.; FAZAN, V. P. S.; THOMAZINI, J. A. \& TIRAPELLI, L. F. Apoptosis in bone defect of diabetic rats treated with low intensity laser: Radiological and immunohistochemical approach. Int. J. Morphol., 35(1):178-183, 2017.

\section{REFERENCES}

Dempster, D. W.; Hughes-Begos, C. E.; Plavetic-Chee, K.; Brandao-Burch, A.; Cosman, F.; Nieves, J.; Neubort, S.; Lu, S. S.; Iida-Klein, A.; Arnett, T. \& Lindsay, R. Normal human osteoclasts formed from peripheral blood monocytes express PTH type 1 receptors and are stimulated by PTH in the absence of osteoblasts. J. Cell. Biochem., 95(1):139-48, 2005.

Dunlop, J. W. C. \& Fratzl, P. Biological composites. Аnпи. Rev. Mater. Res., 40:1-24, 2010.

Einhorn, T. A. The cell and molecular biology of fracture healing. Clin. Orthop. Relat. Res., (355 Suppl.):7-21, 1998.

Fazan, V. P.; Rodrigues Filho, O. A.; Jordão, C. E. \& Moore, K. C. Phrenic nerve diabetic neuropathy in rats: unmyelinated fibers morphometry. $J$. Peripher. Nerv. Syst., 14(2):137-45, 2009.

Fernandes, A. P. M.; Pace, A. E.; Zanetti, M. L.; Foss, M. C. \& Donadi, E. A. Fatores imunogenéticos associados ao diabetes mellitus do tipo 1. Rev. Latinoam. Enferm., 13(5):743-8, 2005.

Garib, D. G.; Henriques, J. F.; Janson, G.; de Freitas, M. R. \& Fernandes, A. Y. Periodontal effects of rapid maxillary expansion with tooth-tissueborne and tooth-borne expanders: a computed tomography evaluation. Am. J. Orthod. Dentofacial Orthop., 129(6):749-58, 2006.

Imao, T. \& Nagata, S. Apaf-1- and Caspase-8-independent apoptosis. Cell Death Differ, 20(2):343-52, 2013.

Leo, J. A.; da Cunha, A.; de Oliveira, E. F. \& Prado, R. P. Effect of lowlevel laser (GaAs, $904 \mathrm{hm})$ for bone repair on fractures in rats. Rev. Bras. Ortop., 47(2):235-40, 2012.

Miserendino, L. J. \& Pick, R. M. Laser in Dentistry. Chicago, Quintessence, 1995. pp.341.

Nascimento, M. F.; Almeida, B. M.; Cunha, J. L.; Valois, R. B.; Pinheiro, J. C.; Ribeiro, M. A.; Lima, S. O. \& Albuquerque-Júnior, R. L. Improvement of bone repair in diabetic rats subjected to $780 \mathrm{~nm}$ lowlevel laser therapy. Acta Cir. Bras., 30(10):660-7, 2015.

Oliveira, F. S.; Nessler, R. A.; Castania J. A.; Salgado, H.C.; Fazan, V. P. Ultrastructural and morphometric alterations in the aortic depressor nerve of rats due to long term experimental diabetes: effects of insulin treatment. Brain Res., 1491:197-203, 2013

Renno, A. C.; McDonnell, P. A.; Parizotto, N. A. \& Laakso, E. L. The effects of laser irradiation on osteoblast and osteosarcoma cell proliferation and differentiation in vitro. Photomed. Laser Surg, 25(4):275-80, 2007.

Rocha Júnior, A. M.; de Oliveira, R. G., Farias, R. E.; de Andrade, L. C. F. \& Aarestrup, F. M. Modulação da proliferação fibroblástica e da resposta inflamatória pela terapia a laser de baixa intensidade no processo de reparo tecidual. An. Bras. Dermatol., 81(2):150-6, 2006.

Sanada, L. S.; Tavares, M. R.; Sato, K. L.; Ferreira, R. da S.; Neubern, M. C.; Castania, J. A.; Salgado, H. C. \& Fazan, V. P. S. Association of chronic diabetes and hypertension in sural nerve morphometry: an experimental study. Diabetol. Metab. Syndr., 7:9, 2015.

Tanimoto, T.; Tsuda, H.; Imazeki, N.; Ohno, Y.; Imoto, I.; Inazawa, J. \& Matsubara, O. Nuclear expression of cIAP-1, an apoptosis inhibiting protein, predicts lymph node metastasis and poor patient prognosis in head and neck squamous cell carcinomas. Cancer Lett., 224(1):14151,2005 .

\author{
Corresponding author: \\ Jairo Pinheiro da Silva \\ Medical School of Ribeirão Preto \\ University of São Paulo \\ Ribeirão Preto \\ 3900, Bandeirantes Avenue \\ Monte Alegre \\ CEP: 14049900 \\ BRAZIL
}

Email: lab.biomol.cirurgia@fmrp.usp.br

Received:13-07-2016

Accepted:05-12-2016 